\title{
Nodose Ganglia-Modulatory Effects on Respiration
}

\author{
K. KACZYŃSKA ${ }^{1}$, M. SZEREDA-PRZESTASZEWSKA ${ }^{1}$ \\ ${ }^{1}$ Laboratory of Respiratory Reflexes, Mossakowski Medical Research Centre, Polish Academy \\ of Sciences, Warsaw, Poland
}

Received June 19, 2012

Accepted November 23, 2012

On-line March 14, 2013

\section{Summary}

The key role of the vagus nerves in the reflex control of breathing is generally accepted. Cardiopulmonary vagal receptors and their afferent connection with the medullary respiratory centers secures the proper regulatory feedback. Section of the vagi at the midcervical level interrupts primary vagal reflexes and those due to activation of lung afferents by neuroactive substances. In this context the present review focuses on the reflex contribution of the inferior (nodose) vagal ganglia to the respiratory pattern, considering that this structure contains perikarya of vagal afferent neurons which house neurotransmitters, neuropeptides and neurochemical substances. In experimental animals with removed sensory input from the lungs (midcervical vagotomy) the following evidence was reported. Transient respiratory suppression in the form of apnoea, occurring after systemic injection of serotonin, adenosine triphosphate and anandamide ( $\mathrm{N}$-arachidonoylethanolamine-endogenous cannabinoid neurotransmitter), which was abrogated by nodose ganglionectomy. Preserved nodoseNTS connection conditioned respiratory depression affecting the timing component of the breathing pattern evoked by N-6cyclopentyl-adenosine (CPA) and inhibition of both respiratory constituents induced by NPY. Stimulatory effect of NPY13-36 on tidal volume required nodosal connection. The cardiovascular effects of majority of the tested substances occurred beyond the nodose ganglia (with exclusion of serotonin and anandamide).

\section{Key words}

Vagus nerve • Nodose ganglion • Respiratory pattern • Apnoea • Neurotransmitters

\section{Corresponding author}

Katarzyna Kaczyńska, Laboratory of Respiratory Reflexes,
Mossakowski Medical Research Centre, Polish Academy of Sciences, 5 Pawiński St., 02-106 Warsaw, Poland. Fax: +48 (22) 6685532. E-mail: kkaczynska@imdik.pan.pl

\section{Introduction}

The vagus nerve secures motor and sensory innervation of the airways. Preganglionic motor vagal neurons are localized in the nucleus ambiguous (nA), dorsal vagal nucleus (DVN) and in reticular formation between them in the brainstem (Loewy and Spyer 1990).

Sensory input from nerve endings in the lungs is mediated to vagal afferent neurons in the lower (nodose, $\mathrm{NG}$ ) and superior (jugular) ganglia. In rats the ganglia are located at distance, the jugular lies intracranially (Zhuo and Helke 1996, Zhuo et al. 1997). In the guinea pigs they are close but clearly separated, as smartly illustrated in the paper by Nassenstein et al. (2010). Both ganglia have different embryological background. The nodose ganglion is derived from epibranchial placodes and the jugular originates from the neural crest cells, which defines the phenotypes of the vagal fibers (Carr and Undem 2003, Undem et al. 2004). The central endings of vagal primary neurons innervating the airways terminate in the nucleus tractus solitarii (NTS) of the medulla oblongata. NTS, NG alike house and releases a variety of neurotransmitters and neuromodulators, which are essential in the regulation of autonomic nervous functions. Primary respiratory vagal reflexes modifying the pattern of breathing, evoked by normal physiological events (lung inflation, activation of chemoreceptors) as well as the effects of chemical substances affecting vagal afferents when injected into the pulmonary circulation, 


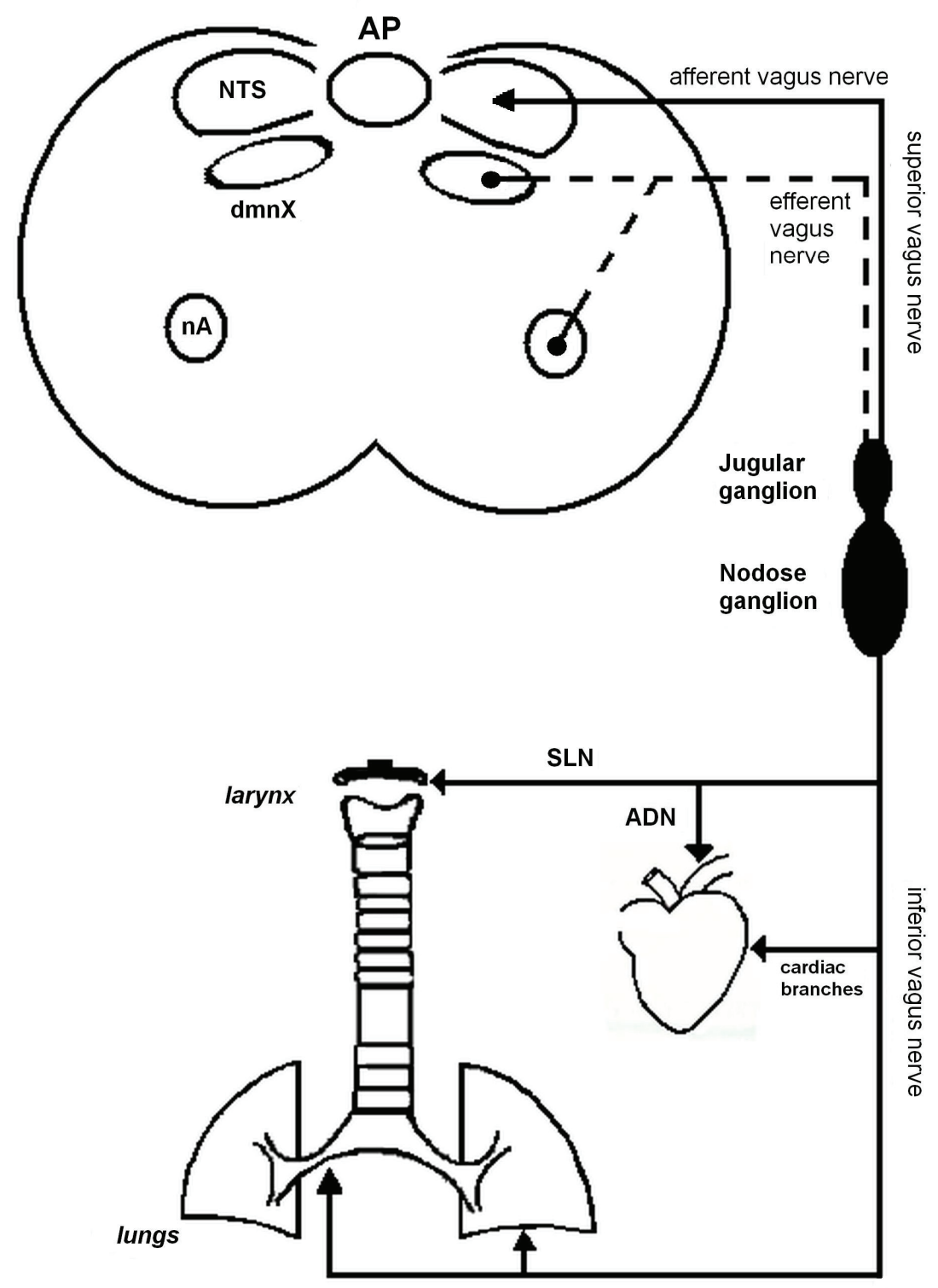

Fig. 1. Schematic drawing of the vagal innervation of the respiratory system and the heart. Abbreviations: AP (area postrema), NTS (nucleus tractus solitarius), dmnX (dorsal motor nucleus of the vagus), $\mathrm{nA}$ (nucleus ambiguous), SLN (superior laryngeal nerve), ADN (aortic depressor nerve)

are prevented by midcervical vagotomy. Multiplicity of ionotropic, G-protein coupled or ion channel-gated receptors on vagal sensory afferent fibers activated by various compounds evidenced with the modern techniques (Undem and Carr 2001) indicates that the higher levels of the vagal pathway might be involved in reflex respiratory responses. The present review concentrates on the contribution of the nodosal pathway to the reflex responses to systemic challenge with various neuroactive substances (Fig. 1).

\section{Lung vagal afferents}

According to the orthodox, accepted division there are three main types of lung vagal afferent endings: (i) slowly adapting pulmonary stretch receptors (SARs), (ii) rapidly adapting receptors (RARs) both with myelinated fibers and (iii) bronchopulmonary nonmyelinated $\mathrm{C}$-fiber afferents. The two latter respond to mechanical, irritant and chemical stimuli in the airways and produce diverse reflex responses: hyperventilation, augmented breaths, bronchoconstriction, decreases in tidal volume, tachypnoea and cardiovascular effects (Sant'Ambrogio and Widdicombe 2001, Lee and Pisarri 2001). The reflex function of SARs is known since the classical work of Hering and Breuer in 1868. It is considered that summation of SARs activity within the brain stem respiratory groups is acting as a mechanism terminating inspiration, resulting in the decrease in tidal volume and shortening of the inspiratory time (Coleridge and Coleridge 1986, Schelegle and Green 2001).

Albeit this classification is hitherto existing, the 
comprehensive research performed in the guinea-pigs, threw a new light on the bronchopulmonary afferent nerves, which belong to above mentioned three categories: C fibers, rapidly adapting stretch receptors, and slowly adapting stretch receptors (Carr and Undem 2003). As addressed in the Introduction the different embryological origin of the vagal nodose and jugular ganglia seems to bring about various functions of the afferent fibers projecting from their somata in the ganglia to the airways. These from the nodose ganglia were in majority rapidly adapting myelinated $\mathrm{A} \delta$, low treshold mechanosensory stretch fibers (RARs and SARs) supplying intrapulmonary airways. Uneven, small quantity of unmyelinated $\mathrm{C}$ fibers projected to intrathoracic airways. Afferents arising form the jugular ganglia, $\mathrm{A} \delta$ adapting slowly to mechanical stimuli and $\mathrm{C}$ fibers, both stimulated by capsaicin, were directed to intrathoracic airways (Riccio et al. 1996, Carr and Undem 2003).

\section{Sites and effects of vagotomy}

Bilateral midcervical vagotomy prevents the respiratory reflexes conveyed by the vagal afferents generated on its sensory endings. Midcervical division of the vagi in cats, rabbits, dogs and rats induces an increase in tidal volume and slowing down of the breathing rate (Lim et al. 1958, Eldridge 1973, Gautier 1973, Paleček and Chválová 1976). The lack of the volume feedback and prolongation of the inspiratory time were reported in dogs, ponies and rabbits following pulmonary vagotomy performed either by hilar stripping of the vagal branches or section of the vagal trunks within the chest (Favier et al. 1982, Flynn et al. 1985 a, b, Clifford et al. 1983, Szereda-Przestaszewska 1986). This neurotomy was evidenced to be effective in eliminating the triad of pulmonary chemoreflex evoked by capsaicin challenge (arrest of breathing, hypotension and bradycardia) in dogs and cats (Toh et al. 1955, Coleridge and Coleridge 1984, Clifford et al.1987, Haxhiu et al. 1988, Kopczyńska and Szereda-Przestaszewska 1998) but not in rats (Kaczyńska and Szereda-Przestaszewska 2000).

Refined, selective sensory vagotomy performed in cats at the level of the nodose ganglia, described first by Mei (1966), has shown that these lung afferents are exclusively involved in the shape of the respiratory pattern while the motor efferents seem to be disregarded (Jammes and Mei 1979).

\section{Neural structure of the nodose ganglia}

Extracranial nodose ganglia of the vagus nerve contain somata of the primary vagal afferent neurons predominantly of $\mathrm{C}$ and residual of $\mathrm{A}$ type fibers (Stansfeld and Wallis 1985). They are pseudounipolar with axon-like process, which bifurcate into the centrally and peripherally directed primary afferent fibers. The peripheral axons compose vagus nerve and its branches and innervate receptors in the respiratory, cardiovascular and gastrointestinal systems. The central axons transmit information from the above mentioned viscera to CNS and terminate in the nucleus of the solitary tract (NTS) in the brainstem (Brodal 1969, Kalia and Mesulam 1980, Donoghue et al. 1982 a, b, Puizillout and Gambarelli 1989, Leal-Cardoso et al. 1993, Zhuo et al. 1997). Supranodosal vagus in the cat was shown to contain about fifty thousands fibers of which scarcely $13 \%$ were myelinated (Mei et al. 1980). Likewise, in bronchial branches non-myelinated fibers constituted $90 \%$ of the sensory and motor vagal components (James et al. 1982). Separate afferent vagal branches - superior laryngeal (SLN) and aortic depressor nerves (ADN) departure from (enter to) the nodose ganglion usually jointly in rats (Andrew 1954, Sapru and Krieger 1977). Both nerves are composed mainly of the myelinated fibers in cats an rabbits (Agostoni et al. 1957, Jordan and Spyer 1978), whereas in rats the proportion of the myelinated fibers accounts for $50 \%$ (SLN) and $20 \%$ for ADN (Hishida et al. 1997, Fazan et al. 1997).

\section{Neurochemical content of the nodose ganglia}

The large body of data obtained from immunohistochemical studies of the nodose ganglia performed in rats detected immunoreactive cells for naturally occurring neuropeptides: substance $P$, calcitonin-gene related peptide, cholecystokinin, neurokinin A, vasoactive intestinal peptide and somatostatin (Helke and Hill 1988, Balzamo et al. 1996). The most extensive and comparable review of Zhuo et al. (1997) on the content of neurochemicals within the neurons of the nodose ganglia reveals classic neurotransmitters, neuropeptides and presence of the defined receptors. Therefore this structure appears to serve as an important regulatory mechanism in the cardiovascular and respiratory control.

Chronic supranodose vagotomy has been generally applied in histological studies on the 
Table 1. Neurotransmitters, neuropeptides and other neuractive substances that evoke respiratory and/or cardiovascular responses mediated by the intact nodose ganglia.

\begin{tabular}{|c|c|c|}
\hline Substances & Response & References \\
\hline Serotonin & Apnea & Jacobs and Comroe (1971) \\
\hline Phenyldiguanide & $\begin{array}{l}\text { Bradycardia } \\
\text { Hypotension }\end{array}$ & \\
\hline Serotonin & Apnea & $\begin{array}{l}\text { Black et al. (1972), Yoshioka et al. (1992), Kopczyńska } \\
\text { and Szereda-Przestaszewska (2003) }\end{array}$ \\
\hline $\begin{array}{l}\text { Adenosine triphosphate } \\
(A T P)\end{array}$ & Apnea & McQueen et al. (1998) \\
\hline Anandamide (AEA) & $\begin{array}{l}\text { Apnea } \\
\text { Decrease in tidal volume } \\
\text { Hypotension }\end{array}$ & Kopczyńska and Szereda-Przestaszewska (2006) \\
\hline $\begin{array}{l}N \text { 6-cyclopentyl- } \\
\text { adenosine (CPA) }\end{array}$ & Decrease in respiratory rate & Kaczyńska and Szereda-Przestaszewska (2008) \\
\hline Neuropeptide Y (NPY) & $\begin{array}{l}\text { Decrease in tidal volume } \\
\text { Decrease in respiratory rate }\end{array}$ & Kaczyńska and Szereda-Przestaszewska (2010) \\
\hline NPY 13-36 & Increase in tidal volume & Kaczyńska and Szereda-Przestaszewska (2011) \\
\hline
\end{tabular}

composition and functions of the nerve fibers contained in the vagus nerve (Agostoni et al. 1957, Mei et al. 1980) and in neurochemical research evidencing neurotransmitters of vagal primary fibers and receptor binding sites within the NTS.

\section{Respiratory impact from the nodose ganglia}

\section{Apnoea}

There is scarce evidence presented in the earlier reports showing that supranodose connection is essential for the occurrence of respiratory effects in animals with disrupted vagal and/or carotid sinus afferents. This applies to serotonin (5HT), a putative neurotransmitter and phenyldiguanide $-5 \mathrm{HT}_{3}$ receptor agonist injected into carotid artery in cats. Respiratory inhibition in the form of apnoea and cardiovascular component: bradycardia and hypotension induced by $5 \mathrm{HT}$ injection were not dependent on the integrity of the lung and carotid bodies sensory innervation. This was pioneered by Jacobs and Comroe (1971) and Black et al. (1972) who showed that section of the supranodose vagi abolished the apnoea. This respiratory arrest resulted from the direct excitatory effect of 5HT on nodose ganglion cells (Sampson and Jaffe 1974), and was reported before serotonin receptors were described (Peroutka and Snyder 1979). The apnoeic effects of the local injection of 5HT into vascularly isolated nodose ganglion reinforced this site of action (Sutton 1981). Since then it became clear that the majority of vagal afferent neurons are endowed with 5HT receptors (Higashi and Nishi 1982). However, the blockade of two types of 5HT receptors appeared not to be as effective as the transection of the supranodose vagi to abolish post$5 \mathrm{HT}$ apnoea induced by systemic challenge in rats and cats (Yoshioka et al. 1992, Kopczyńska and SzeredaPrzestaszewska 2003). Therefore this body of data indicates that projections issues from the nodose ganglia in midcervically vagotomized animals contribute to the respiratory suppression after challenge with some neurochemical substances endogenous to ganglionic neurons. This relates to the apnoeic effects evoked by stimulation of $\mathrm{P}_{2 \mathrm{X}}$ purinoceptors (receptors for adenosine triphosphate) and endocannabinoid receptors in rats (McQueen et al. 1998, Kopczyńska and SzeredaPrzestaszewska 2006) (Table 1).

\section{Respiratory depression and stimulation}

Respiratory inhibition other than apnoea induced by neurochemicals appears to be less described. Several lines of evidence suggest that adenosine $\mathrm{A}_{1}$ receptors, endowing the nodosal neurons (Lawrence et al. 1997), when activated by systemic challenge with the appropriate agonist (N 6-cyclopentyl-adenosine) caused inhibition of both constituents of the respiratory pattern: tidal volume and respiratory rate in midcervically 
vagotomized rats. Supranodose vagotomy prevented the decrease in breathing frequency and showed no effect on the depression of tidal volume. Pretreatment with $A_{1}$ receptor antagonist (DPCPX) effectively blocked these respiratory responses. Modulation of frequency and volume was therefore attributed separately to activation of $A_{1}$ nodosal and central receptors, respectively (Kaczyńska and Szereda-Przestaszewska 2008).

Neurotransmitters/neuromodulators present in mammalian brain and residing also in the periphery have been seldom tested in experimental animals. Relatively little data are available on respiratory effects of the endogenous non-opioid neuropeptides. It is generally assumed that they induce respiratory depression. Receptors for neuropeptide $\mathrm{Y}$ : $\mathrm{Y}_{1}$ and $\mathrm{Y}_{2}$ were described to be localized in the nodose ganglia of rabbits, human and rats (Ghilardi et al. 1994, McLean et al. 1997, Coelho et al. 2004). Systemic pretreatment of midcervically vagotomized rats with neuropeptide $\mathrm{Y}$ (NPY) was shown to produce bradypnoea with decreased tidal volume. These effects were prevented and reduced by bilateral nodosectomy, respectively. Contrary to NPY, an intravenous injection of NPY13-36, the agonist of $\mathrm{Y}_{2}$ receptors, evoked respiratory facilitation by stimulating the pattern of breathing in neurally intact rats. The increase in the frequency response appeared to rely on sensory input from the lungs, whereas augmentation in tidal volume was mediated by the supranodose connection.

Intravenous pretreatment with the selective antagonists eliminated the respiratory effects of excitation of $Y_{1}$ and $Y_{2}$ receptors. These data indicate that NPY induced depressive effects on respiration are mediated via nodosal and supranodosal $Y_{1}$ receptors feedback, whereas $\mathrm{Y}_{2}$ enhanced respiratory drive requires modulation of infra and supranodose pathway (Kaczyńska and SzeredaPrzestaszewska 2010, 2011).

\section{Extranodosal cardiovascular changes}

The cardiovascular alterations resulting from challenge with adenosine agonist (bradycardia and hypotension), NPY (bradycardia and hypertension) and NPY13-36 (invariable HR and hypertension) did not reside in supranodose connection, but appeared to be effectively antagonized by the respective receptors' blockers (Kaczyńska and Szereda-Przestaszewska 2008, 2010, 2011). It is of note that earlier findings inferred the occurrence of cardiovascular effects of 5HT beyond the afferentation from the nodose ganglia in cats (Jacobs and
Comroe 1971, Sampson and Jaffe 1974). Subsequent data revealed that lesioned supranodose pathway prevented the hypotensive effects of 5HT in rats and cats (Orer et al. 1991, Yoshioka et al. 1992, Kopczyńska and SzeredaPrzestaszewska 2003).

Mechanism underlying the hypotensive action of adenosine we have tested seems to rely on mediation through the peripheral $A_{1}$ receptors expressed in the heart and vasculature (Shryock and Belardinelli 1997, Tabrizchi and Bedi 2001), producing vasodilatation either via release of other neurotransmitters (Hedner et al. 1982, Stella et al. 1993) or modulation from the peripheral $\mathrm{A}_{1}$ receptors (Schindler et al. 2005). $\mathrm{Y}_{1}$ and $\mathrm{Y}_{2}$ receptors located on the vascular smooth muscles (Tessel et al. 1993, Pedrazzini et al. 1998), activated with respective agonists were reported to increase blood pressure (Corder et al. 1986, Abrahamsson 2000, Kaczyńska and SzeredaPrzestaszewska 2010, 2011). Further experimental data to support these findings are abridged. However, it is important to stress that NPY mimics the cardiovascular effects of catecholamines (van Giersbergen et al. 1992).

Limited number of publications dealing with the contribution of the nodose ganglia to regulation of the respiratory reflexes renders an ample consideration perplexing. It is difficult to generalize the evidence provided in this review article. Together, these data suggest that neuroactive substances (adenosine, neuropeptide $\mathrm{Y}$ ) in inhibiting the respiratory drive do not require sensory input from the lungs. They have a predominant bradypnoeic effect on the timing component of the breathing pattern mediated via the supranodose feedback. Evidence to support this concept includes the observation that the coincident inhibition of tidal volume revealed by both substances occurred beyond the supranodosal connection.

It is to be emphasized that in stimulated breathing induced by NPY 13-36, tachypnoea relied on lung vagal pathway, whereas augmentation in tidal volume was attributed to the nodosal connection. It is noteworthy, as formerly mentioned, that the respiratory suppression in the form of apnoea, evoked by activation of serotonin, endocannabinoid and adenosine triphosphate receptors abounded in nodose ganglia requires supranodose feedback.

\section{Conclusions}

It was reported earlier that vagotomy or inhibition of axoplasmic transport changes the expression 
of neuropeptides in neurones of the nodose ganglia (Zhuo et al. 1995) and more recent studies have shown decreased excitability of these neurones after vagotomy (Porreca et al. 1999, Lancaster et al. 2001). There is no relevant research on such effects of nodosectomy, but it could be inferred from the above evidence that destruction of the supranodosal pathway unsettles transduction from the primary vagal sensory neurones to the binding sites for neurotransmitters within NTS subnuclei and this might variably affect the constituents of the breathing pattern.

\section{Conflict of Interest}

There is no conflict of interest.

\section{References}

ABRAHAMSSON C: Neurpopeptide $\mathrm{Y}_{1}$ and $\mathrm{Y}_{2}$-receptor- mediated cardiovascular effects in the anaesthetized guineapig, rat, and rabbit. $J$ Card Pharm 36: 451-458, 2000.

AGOSTONI E, CHINNOCK JE, DE BURGH DALY M, MURRAY JG: Functional and histological studies of the vagus nerve and its branches to the heart, lungs and abdominal viscera in the cat. J Physiol 135: 182-205, 1957.

ANDREW BL: A laryngeal pathway for aortic baroreceptor impulses. J Physiol 125: 352-360, 1954.

BALZAMO E, JOANNY P, STEINBERG JG, OLIVER C, JAMMES Y: Mechanical ventilation increases substance P concentration in the vagus, sympathetic, and phrenic nerves. Am J Respir Crit Care Med 153: 153-157, 1996.

BLACK AMS, COMROE JH, JACOBS L: Species difference in carotid-body response of cat and dog to dopamine and serotonin. Am J Physiol 223: 1097-1102, 1972.

BRODAL A: Neurological Anatomy in Relation to Clinical Medicine. Oxford University Press, London, N.Y., 1969, pp. 363-374.

CARR MJ, UNDEM BJ: Bronchopulmonary afferent nerves. Respirology 8: 291-301, 2003.

CLIFFORD PS, COON RL, VON COLDITZ JH, ZUPERKU EJ, KAMPINE JP: Pulmonary denervation in the dog. J Appl Physiol 54: 1451-1456, 1983.

CLIFFORD PS, LITZOW JT, COON RL: Pulmonary depressor reflex elicited by capsaicin in conscious intact and lung-denervated dogs. Am J Physiol 252: R394-R397, 1987.

COELHO EF, FERRARI MFR, MAXIMINO JR, FIOR-CHADI DR: Changes in the expression of NPY receptor subtypes Y1 and Y2 in central and peripheral neurons related to the control of blood pressure in rats following experimental hypertension. Neuropeptides 38: 77-82, 2004.

COLERIDGE HM, COLERIDGE JCG: Afferent vagal C fibre innervation of the lungs and airways and its functional significance. Rev Physiol Biochem Pharmacol 99: 1-110, 1984.

COLERIDGE HM, COLERIDGE JCG: Reflexes evoked from tracheobronchial tree and lungs. In: Handbook of Physiology, Section 3: The Respiratory System. Vol. II: Control of Breathing. NS CHERNIACK, JG WIDDICOMBE (eds), American Physiological Society, Bethesda, MD, 1986, pp. 395-429.

CORDER R, LOWREY PJ, WILKINSON SJ, RAMAGE AG: Comparison of the haemodynamic actions of neuropeptide Y, angiotensin and noradrenaline in anaesthetized cats. Eur J Pharmacol 121: 25-30, 1986.

DONOGHUE S, GARCIA M, JORDAN D, SPYER KM: Identification and brain-stem projections of aortic baroreceptor afferent neurones in nodose ganglia of cats and rabbits. J Physiol 322: 337-352, 1982 a.

DONOGHUE S, GARCIA M, JORDAN D, SPYER KM: The brain-stem projections of pulmonary stretch afferent neurones in cats and rabbits. $J$ Physiol 322: 353-363, 1982 b.

ELDRIDGE FL: Relationship between phrenic nerve activity and ventilation. Am J Physiol 221: 535-543, 1971.

FAVIER R, KAPENECHIAN G, DESPLANCHES D, FLANDROIS R: Effects of chronic lung denervation on breathing pattern and respiratory gas exchanges during hypoxia, hypercapnia and exercise. Respir Physiol 47: 107-119, 1982.

FAZAN VPS, SALGADO HC, BARREIRA AA: A descriptive and quantitative light and electron microscopy of the aortic depressor nerve in normotensive rats. Hypertension 30: 693-698, 1997.

FLYNN C, FORSTER HV, PAN LG, BISGAARD GE: Role of hilar nerve afferents in hyperpnoea of exercise. J Appl Physiol 59: 798-806, 1985a. 
FLYNN C, FORSTER HV, PAN LG, BISGAARD GE: Effect of hilar nerve denervation on breathing and arterial $\mathrm{PCO}_{2}$ during $\mathrm{CO}_{2}$ inhalation. $J$ Appl Physiol 59: 807-813, 1985 b.

GAUTIER H: Respiratory responses of the anaesthetized rabbit to vagotomy and thoracic dorsal rhizotomy. Respir Physiol 17: 238-247, 1973.

GHILARDI JR, ALLEN CJ, VIGNA SR, MCVEY DC, MANTYH PW: Cholecystokinin and neuropeptide Y receptors on single rabbit vagal afferent ganglion neurons: site of prejunctional modulation of visceral sensory neurons. Brain Res 633: 33-40, 1994.

HAXHIU MA, VAN LUNTEREN E, DEAL EC, CHERNIACK NS: Effect of stimulation of pulmonary C-fiber receptors on canine respiratory muscles. J Appl Physiol 65: 1087-1092, 1988.

HEDNER T, HEDNER J, JONASON J: Regulation of breathing in the rat: indications for a role of central adenosine mechanisms. Neurosci Lett 33: 147-151, 1982.

HELKE CJ, HILL KM: Immunohistochemical study of neuropeptides in vagal and glossopharyngeal afferent neurons in the rat. Neuroscience 20: 539-551, 1988.

HIGASHI H, NISHI S: 5-Hydroxytryptamine receptors of viscetal primary afferent neurons on rabbit nodose ganglia. J Physiol 323: 543-567, 1982.

HISHIDA N, TSUBONE H, SUGANO S: Fiber composition of the superior laryngeal nerve in rats and guinea pigs. J Vet Med Sci 59: 499-501, 1997.

JACOBS L, COMROE JH: Reflex apnoea, bradycardia, and hypotension produced by serotonin and phenyldiguanide acting on the nodose ganglia of the cat. Circ Res 29: 145-155, 1971.

JAMMES Y, MEI N: Assessment of the pulmonary origin of bronchoconstrictor vagal tone. J Physiol 291: 305-316, 1979.

JAMMES Y, FORNARIS E, MEI N, BARRAT E: Afferent and efferent components of the bronchial vagal branches in cats. J Auton Nerv Sys 5: 165-176, 1982.

JORDAN D, SPYER KM: The distribution and excitability of myelinated aortic nerve afferent terminals. Neurosci Lett 8: 113-117, 1978.

KACZYŃSKA K, SZEREDA-PRZESTASZEWSKA M: Respiratory effects of capsaicin occur beyond the lung vagi in anaesthetized rats. Acta Neurobiol Exp 60: 159-165, 2000.

KACZYŃSKA K, SZEREDA-PRZESTASZEWSKA M: The potential role of the nodose ganglion adenosine $\mathrm{A}_{1}$ receptor in regulation of breathing in anaesthetized rats. J Physiol Pharmacol 59: 759-770, 2008.

KACZYŃSKA K, SZEREDA-PRZESTASZEWSKA M: NPY Y ${ }_{1}$ receptors are involved in cardio-respiratory responses to intravenous injection of neuropeptide $Y$ in anaesthetized rats. Pharmacol Res 62: 444-449, 2010.

KACZYŃSKA K, SZEREDA-PRZESTASZEWSKA M: Activation of neuropeptide $\mathrm{Y}_{2}$ receptors exerts an excitatory action on cardio-respiratory variables in anaesthetized rats. Neuropeptides 45: 281-286, 2011.

KALIA M, MESULAM MM: Brainstem projections of sensory and motor components of the vagus complex in the cat. I. The cervical vagus and nodose ganglion. J Comp Neurol 193: 435-465, 1980.

KOPCZYŃSKA B, SZEREDA-PRZESTASZEWSKA M: Apnoeic responses to pulmonary and systemic challenge of capsaicin in cats. $J$ Physiol Pharmacol 49: 25-35, 1998.

KOPCZYŃSKA B, SZEREDA-PRZESTASZEWSKA M: Supranodose vagotomy precludes reflex respiratory responses to serotonin in cats. $J$ Biomed $S c i$ 10: 718-724, 2003.

KOPCZYŃSKA B., SZEREDA-PRZESTASZEWSKA M: Supranodose vagotomy eliminates anandamide-evoked cardiorespiratory depression in anaesthetized rats. Respir Physiol Neurobiol 152: 143-151, 2006.

LANCASTER E, OH EJ, WEINREICH D: Vagotomy decreases excitability in primary vagal afferent somata. J Neurophysiol 85: 247-253, 2001.

LAWRENCE AJ, KRSTEW E, JARROT B: Complex interactions between nitric oxide and adenosine receptors in the rat isolated nodose ganglion. Eur J Pharmacol 328: 83-88, 1997.

LEAL-CARDOSO H, KOSCHORKE GM, TAYLOR G, WEINREICH D: Electrophysiological properties and chemosensitivity of acutely isolated nodose ganglion neurons of the rabbit. J Auton Nerv Syst 45: 29-39, 1993.

LEE LY, PISARRI TE: Afferent properties of reflex functions of bronchopulmonary C-fibers. Respir Physiol 125: 47$65,2001$. 
LIM TPK, LUFT UC, GRODINS F: Effects of cervical vagotomy on pulmonary ventilation and mechanics. $J$ Appl Physiol 13: 317-324, 1958.

LOEWY AD, SPYER KM: Vagal preganglionic neurons. In: Central Regulation of Autonomic Functions. AD LOEWY, KM SPYER (eds), Oxford University Press, New York, 1990, pp. 68-87.

MCLEAN KJ, JARROTT B, LAWRENCE AJ: Prepro-neuropeptide Y mRNA and NPY binding sites in human inferior vagal ganglia. Neuroreport 8: 2317-2320, 1997.

MCQUEEN DS, BOND SM, MOORES C, CHESSELL I, HUMPHREY PPA, DOWD E: Activation of P2X receptors for adenosine triphosphate evokes cardiorespiratory reflexes in anaesthetized rats. $J$ Physiol 507: 843-855, 1998.

MEI N: Existence d'une séparation anatomique des fibres vagales efférentes et afférents au niveau du ganglion plexiforme du Chat. Etude morphologique et électrophysiologique. J Physiol (Paris) 58: 253-254, 1966.

MEI N, CONDAMIN M, BOYER A: The composition of the vagus nerve of the cat. Cell Tissue Res 209: 423-431, 1980.

NASSENSTEIN C, TAYLOR-CLARK TE, MYERS AC, RU F, NANDIGAMA R, BETTNER W, UNDEM BJ: Phenotypic distinctions between neural crest and placodal derived vagal C-fibres in mouse lungs. $J$ Physiol 588: 4769-4783, 2010.

ORER HS, MERAHI N, NOSJEAN A, FATTACCINI CM, LAGUZZI R: Cardiovascular effects of the local injection of 5,7-dihydroxytryptamine into the nodose ganglia and nucleus tractus solitarius in awake freely moving rats. Brain Res 553: 123-128, 1991.

PALEČEK F, CHVÁLOVÁ M: Pattern of breathing in the rat. Physiol Bohemoslov 25: 159-166, 1976.

PEDRAZINI T, SEYDOUX J, KUNSTNER P, AUBERT JF, GROUZMANN E, BEERMANN F: Cardiovascular response, feeding behaviour and locomotor activity in mice lacking the NPY1 receptor. Nat Med 4: 722-726, 1998.

PEROUTKA SJ, SNYDER SH: Multiple serotonin receptors: differential binding of $\left[{ }^{3} \mathrm{H}\right]-5$-hydroxytryptamine, $\left[{ }^{3} \mathrm{H}\right]$-lysergic acid diethylamide and $\left[{ }^{3} \mathrm{H}\right]$-spiraperidol. Mol Pharm 16: 687-699, 1979.

PORRECA F, LAI J, BIAN D, WEGERT S, OSSIPOV MH, EGLEN RM, KASSOTAKIS L, NOVAKOVIC S, RABERT DK, SANGAMESWARAN L, HUNTER JC: A comparison of the potential role of the tetrodotoxininsensitive sodium channels, PN3/SNS and NaN/SNS2, in rat models of chronic pain. Proc Natl Acad Sci (USA) 96: 7640-7644, 1999.

PUIZILLOUT JJ, GAMBARELLI F: Electrophysiological and morphological properties of type C vagal neurons in the nodose ganglia of the cat. J Auton Nerv Syst 29: 49-58, 1989.

RICCIO MM, KUMMER W, BIGLARI B, MYERS AC, UNDEM BJ: Interganglionic segregation of distinct vagal afferent fibre phenotypes in guinea-pig airways. J Physiol 496: 521-530, 1996.

SAMPSON SR, JAFFE RA: Excitatory effects of 5-hydroxytryptamine, veratridine and phenyl diguanide on sensory ganglion cells of the nodose ganglion of the cat. Life Sci 15: 2157-2165, 1974.

SANT'AMBROGIO G, WIDDICOMBE J: Reflexes from airway rapidly adapting receptors. Respir Physiol 125: 3345, 2001.

SAPRU HN, KRIEGER AJ: Carotid and aortic chemoreceptor function in the rat. J Appl Physiol 42: 344-348, 1977.

SCHELEGLE ES, GREEN JF: An overview of the anatomy and physiology of slowly adapting pulmonary stretch receptors. Respir Physiol 125: 17-31, 2001.

SCHINDLER CW, KARCZ-KUBICHA M, THONDIKE EB, MULLER CE, TELLA SR, FERRE S, GOLDBERG SR: Role of central and peripheral adenosine receptors in the cardiovascular responses to intraperitoneal injections of adenosine A1 and A2 subtype receptor agonists. Br J Pharmacol 144: 642-650, 2005.

SHRYOCK JC, BELARDINELLI L: Adenosine and adenosine receptors in the cardiovascular system: biochemistry, physiology, and pharmacology. Am J Cardiol 79: 2-10, 1997.

STANSFELD CE, WALLIS DI: Properties of visceral primary afferent neurons in the nodose ganglion of rabbit. J Neurophysiol 54: 245-260, 1985.

STELLA L, BERRINO L, MAIONE S, DE NOVELLIS V, ROSSI F: Cardiovascular effects of adenosine and its analogs in anaesthetized rats. Life Sci 53: 755-763, 1993. 
SUTTON PMI: The interaction between reflex apnoea and bradycardia produced by injection 5-HT into the nodose ganglion of the cat. Pflügers Arch 389: 181-187, 1981.

SZEREDA-PRZESTASZEWSKA M: Respiratory effects of chronic intrathoracic vagotomy. Respiration 49: 122-129, 1986.

TABRIZCHI R, BEDI S: Pharmacology of adenosine receptors in vasculature. Pharmacol Ther 91: 133-147, 2001.

TESSEL RE, MILLER DW, MISSE GA, DONG X, DOUGHTY MB: Characterization of vascular postsynaptic neuropeptide $\mathrm{Y}$ receptor function and regulation. 1. NPY-induced constriction in isolated rat femoral artery rings is mediated by both Y1 and Y2 receptors: evidence from benextramine protection studies. $J$ Pharmacol Exp Ther 265: 172-177, 1993.

TOH CC, LEE TS, KIANG AK: The pharmacological actions of capsaicin and analogues. Br J Pharmacol 10: 175-182, 1955.

UNDEM BJ, CARR MJ: Pharmacology of airway afferent nerve activity. Respir Res 2: 234-244, 2001.

UNDEM BJ, CHUAYCHOO S, LEE MG, WEINREICH D, KOLLARIC M: Subtypes of vagal afferent C-fibres in guinea-pig lungs. $J$ Physiol 556: 905-917, 2004.

VAN GIERSBERGEN PLM, PALKOVITS M, DE JONG W: Involvement of neurotransmitters in the nucleus tractus solitarii in cardiovascular regulation. Physiol Rev 72: 789-824, 1992.

YOSHIOKA M, GODA Y, TOGASHI H, MATSUMOTO M, SAITO H: Pharmacological characterization of 5hydroxytryptamine-induced apnoea in the rat. J Pharmacol Exp Ther 260: 917-924, 1992.

ZHUO H, HELKE CJ: Presence and localization of neurotrophin receptor tyrosine kinase (TrkA, TrkB, TrkC) mRNAs in visceral afferent neurons of the nodose and petrosal ganglia. Mol Brain Res 38: 63-70, 1996.

ZHUO H, LEWIN AC, PHILLIPS ET, SINCLAIR CM, HELKE CJ: Inhibition of axoplasmic transport in the rat vagus nerve alters the numbers of neuropeptide and tyrosine hydroxylase messenger RNA-containing and immunoreactive visceral afferent neurons of the nodose ganglion. Neuroscience 66: 175-187, 1995.

ZHUO H, ICHIKAWA H, HELKE CJ: Neurochemistry of the nodose ganglion. Progr Neurobiol 52: 79-107, 1997. 